\title{
Incidence and severity of ryegrass staggers and liveweight gain in lambs grazing different mixtures of ryegrass-cocksfoot pastures
}

\author{
M.G. HYSLOP ${ }^{2}$, M.W. FISHER ${ }^{1}$, D.R. SMITH ${ }^{1}$, M.W.A. SLAY ${ }^{1}$, C.A.M. MOFFAT ${ }^{1}$ and P.D. JOHNSTONE ${ }^{3}$ \\ ${ }^{1}$ AgResearch, Poukawa Research Station, P.O. Box 8144, Havelock North \\ 2 AgResearch, Canterbury Agriculture \& Science Centre, P.O. Box 60, Lincoln \\ ${ }^{3}$ AgResearch, Invermay Agricultural Centre, PB 50034, Mosgiel \\ mark.hyslop@agresearch.co.nz
}

\begin{abstract}
Livestock grazing ryegrass infected with endophytic fungi are susceptible to staggers, a neurological disorder characterised by uncoordinated movement and loss of appetite. A possible strategy to minimise staggers is to dilute the toxic effects of ryegrass by providing other non-toxic pasture species in the diet. Therefore, the incidence and severity of ryegrass staggers, and liveweight gain, was monitored in lambs grazing varying mixtures of ryegrass-cocksfoot pastures during four six-week periods throughout summer and autumn over two years. There was a significant effect of pasture type on staggers. On a scale of 0 (no staggers) to 5 (severe muscular tremors invariably resulting in collapse and tetanic spasm), pure ryegrass resulted in a mean of 3.1 , S.E.M. \pm 1.6 compared with 0.3 , S.E.M. \pm 0.9 with pure cocksfoot. Ryegrass/cocksfoot mixtures were slightly less toxic than pure ryegrass with means $( \pm$ S.E.M.) ranging from 2.2 , S.E.M. \pm 1.6 to 2.9 , S.E.M. \pm 1.8 . Mean liveweight gains ranged from $62 \mathrm{~g} / \mathrm{d}$ on both pure ryegrass and 80:20 ryegrass:cocksfoot mix, to $83 \mathrm{~g} / \mathrm{d}$ on pure cocksfoot, with no significant effect of pasture type. In those periods when ryegrass staggers was significant, the percentage of ryegrass in the sward was positively related to the severity of staggers and negatively correlated with liveweight gain. The inclusion of cocksfoot in ryegrass-dominant pastures is thus able to reduce to some extent the adverse neurological effects of endophyte on lambs.
\end{abstract}

Keywords: cocksfoot, endophyte, lambs, liveweight gain, ryegrass, ryegrass staggers

\section{Introduction}

Most, though not all, perennial ryegrass pastures are naturally infected with the endophytic fungus Neotyphodium lolii, imparting a degree of insect resistance to the plant, especially giving protection against Argentine stem weevil (Listronotus bonariensis) and discouraging overgrazing by stock (Prestidge 1993; Easton 1999). The endophyte produces a number of alkaloids, one of which, Lolitrem $B$, is the major cause of ryegrass staggers (Gallagher et al. 1981). This neurological disorder is characterised by uncoordinated movement and loss of appetite (Keogh 1973), and is often seen in stock grazing perennial ryegrass dominant pastures. Cattle, sheep, deer and horses are susceptible, with affected sheep having significantly reduced liveweight gains (Fletcher 1983; Fletcher \& Borrell 1984; Fletcher et al. 1999). Furthermore, these animals are difficult to move, and may become immobile and occasionally die of starvation, dehydration or misadventure. Management routines can be disrupted, often at mating time, and occasionally severe outbreaks may result in significant stock deaths (Milne et al. 1999).

Several strategies have been investigated to avoid the deleterious effects of ryegrass staggers. These include feeding animals non-toxic forage, either low or toxin-free endophyte ryegrass, or other grass species to either reduce the incidence of staggers, or allow animals to detoxify after infection (Bluett et al. 1997; Milne et al. 1997; Popay et al. 1999). Similarly, rotational grazing routines may enable herbage regrowth of reduced endophyte content (Keogh 1983; Keogh \& Clements 1993). Other strategies have included prophylactic treatment of animals with liquid seaweed (McKenzie 1982; McKenzie \& Everest $1985)$ and selecting animals for resistance to staggers (Morris et al. 1995, 1998).

A further possibility is that of diluting the toxic effects of ryegrass, by offering significant amounts of other, non-toxic, species in the pasture of grazing stock. A survey of pastoral farmers (Korte \& Smith 1993) reported that the risk of ryegrass staggers may be lower in mixed ryegrass/cocksfoot pastures than in those containing ryegrass alone. The objective of the current experiment was to determine whether increasing levels of cocksfoot herbage in ryegrass pastures would affect the incidence and severity of ryegrass staggers in growing ewe lambs. The pastures were established specifically for the experiment and grazed over a three-year period.

\section{Materials and methods \\ Pasture establishment and experimental design}

Five ryegrass (Grasslands Nui containing a high proportion of seed infected with wild-type endophyte) 
and cocksfoot (Grasslands Wana) pastures were established as $20 \mathrm{~m}$ x $80 \mathrm{~m}$ plots in the autumn of 1994 at Poukawa Research Station $\left(39^{\circ} 45^{\prime} \mathrm{S}, 176^{\circ} 43^{\prime} \mathrm{E}\right)$, Hawkes Bay, following herbicide (glyphosate) application and conventional cultivation of an area of old, established, mixedsward pasture. Pastures were sown in a randomised complete block design with two replicate treatments of the following ratio of sowing rates of approximately (1) $100 \%$ ryegrass $(20 \mathrm{~kg} / \mathrm{ha}),(2) 80 \%$ ryegrass, $20 \%$ cocksfoot (16 kg/ha and $4 \mathrm{~kg} / \mathrm{ha}$, respectively), (3) $75 \%$ ryegrass, $25 \%$ cocksfoot $(13 \mathrm{~kg} / \mathrm{ha}$ and $4 \mathrm{~kg} / \mathrm{ha}$, respectively), (4) $60 \%$ ryegrass, $40 \%$ cocksfoot (10 $\mathrm{kg} / \mathrm{ha}$ and $6 \mathrm{~kg} / \mathrm{ha}$, respectively), and (5) $100 \%$ cocksfoot $(10 \mathrm{~kg} / \mathrm{ha})$ for each treatment respectively. The plots were maintained by light grazing and mowing (to $5-8 \mathrm{~cm}$ ) of seedheads to maintain pasture quality prior to the first period of experimental grazing 12 months after establishment. Depending on herbage mass (1057 - $3050 \mathrm{~kg} \mathrm{DM} / \mathrm{ha})$ on offer, each plot was grazed by 6-8 ewe lambs (6-8 months of age) during each of two autumn and two summer periods, 1-3 years after pastures were established (Table 1). Between experimental grazings, phosphate and urea fertilisers were applied routinely, thistles removed by grubbing and pastures maintained by grazing with dry stock and mowing of seedheads.

\section{Measurements}

Pasture composition was recorded on two occasions. At three months (July 1994) after establishment, plants were identified and counted in $12,15 \times 30 \mathrm{~cm}$ quadrants per plot. Two years later (July 1996), a point analysis was undertaken on fixed transects monitoring 200 points on each plot. Pasture samples were collected at the start and end of each grazing period for mass and morphological composition. In addition, during the final grazing period (summer 1997), pasture mass and morphological composition (grass leaf, stem, seedhead, pseudostem, white and subterranean clover, other legumes, weeds, grasses and dead material) were monitored at weekly intervals (Figure 2).

Lamb live weights were measured following an overnight fast immediately prior to, and at the completion of each grazing period. Ryegrass staggers were scored at the completion of each grazing period according to Keogh (1973). The lambs were briskly moved $320 \mathrm{~m}$ (4 plot lengths) and scored, where $0=$ no symptoms and $5=$ severe muscle tremors elicited by slight disturbance or exercise invariably resulting in staggering and collapse in a severe tetanic spasm.

\section{Statistical analyses}

The incidence and severity of ryegrass staggers were analysed using a generalised linear model (McCullagh et al. 1983) after classing staggers as either absent (score 0 ), minimal (scores 1 and 2), moderate (scores 3 and 4) and severe (score 5). The model incorporated the following factors: class of staggers, plot, grazing period, and pasture treatment. Lamb liveweight gain was expressed as g/day and analysed by REML (Payne 1993). Results are expressed as the mean, plus or minus the standard error of the mean $( \pm$ SEM), or as a range.

\section{Results}

\section{Pasture}

Pasture composition between treatments measured three months after establishment, and two years later, ranged from ryegrass dominant with no cocksfoot, to mixtures of both species, to cocksfoot dominant with little ryegrass (Table 2). The pasture on offer at the beginning of grazing averaged $1990 \mathrm{~kg} / \mathrm{DM} / \mathrm{ha}$ (range 1060 - 3050), and the residual at the end of grazing was 750 (range $160-1720) \mathrm{kg} / \mathrm{DM} / \mathrm{ha}$ (Table 3 ). Herbage available on each pasture treatment was similar (Table 3, P> 0.05), but varied between seasons.

\section{Animal performance}

The variation in individual lamb growth rates over the experiment was immense, ranging from -82 to $238 \mathrm{~g}$ /day. Mean liveweight gains ranged from $62 \mathrm{~g} /$ day on pure ryegrass and 80:20 ryegrass:cocksfoot mix to $83 \mathrm{~g} /$ day on pure cocksfoot (Table 3), with no significant effect of pasture type. Clinical signs of ryegrass staggers were detected in more than threequarters of lambs grazing pure ryegrass or ryegrasscocksfoot mixtures, while few lambs (13\%) grazing cocksfoot alone displayed symptoms. While the addition of cocksfoot to ryegrass pasture did not affect the number of lambs with staggers (Table 4), it 
Figure 2 Morphological components of the swards and the ryegrass staggers score during the summer (1997) grazing period.

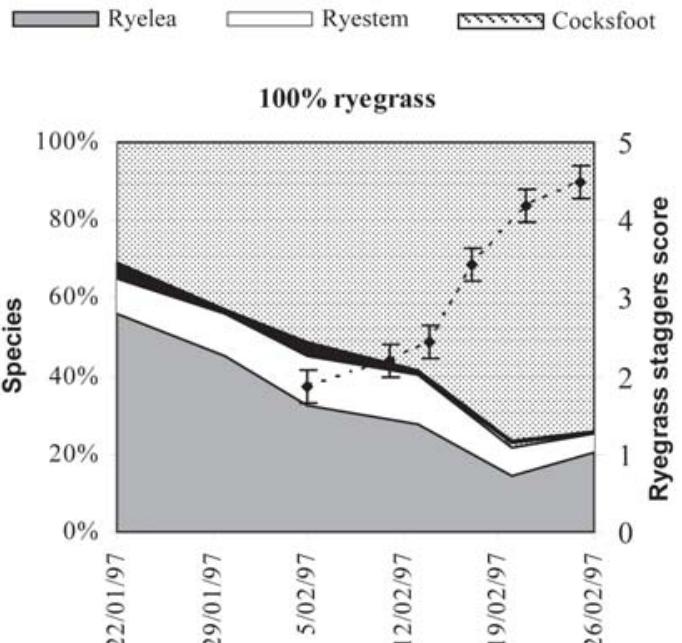

Other $\ldots$ Dead $\quad \cdots \cdots$ Staggers

\section{$75 \%$ ryegrass, $25 \%$ cocksfoot}

significantly reduced the severity of the symptoms. Moderate or severe symptoms were evident in $71 \%$ of lambs grazing pure ryegrass, only $57 \%$ were similarly affected when cocksfoot was included in the pasture (Table 4). Few lambs $(<5 \%) \quad$ showed moderate or severe symptoms when grazing pure cocksfoot. There were significant $(\mathrm{P}<0.01)$ effects of the grazing period, with few lambs displaying staggers in the first autumn (mean staggers score of $0.3 \pm 0.10)$ compared with subsequent grazing periods $(2.4 \pm 0.16$ for the following summer, $3.2 \pm 0.20$ autumn and $2.9 \pm 0.19$, and summer periods, respectively). Limiting the analysis to the grazing periods where staggers was frequent revealed a significant positive relationship between the percentage of ryegrass in each plot at the beginning of grazing and the severity of staggers $(\mathrm{P}<0.01)$. As the proportion of ryegrass on offer increased, the mean staggers score tended to increase linearly (Figure 1). The relationship with liveweight gain was similarly linearly significant $(\mathrm{P}<0.01)$, average liveweight gain decreased as the amount of ryegrass in the sward increased (Figure 1).

Table 2 Composition (\%) of ryegrass, cocksfoot and ryegrass-cocksfoot pastures counted in $15 \times 30 \mathrm{~cm}$ quadrants on each plot three months after sowing and again by point analysis two years after sowing.

\begin{tabular}{lccccc}
\hline $\begin{array}{l}\text { Time from } \\
\text { establishment }\end{array}$ & $\begin{array}{c}\text { Pure } \\
\text { ryegrass }\end{array}$ & $\begin{array}{c}80: 20 \\
\text { ryegrass- } \\
\text { cocksfoot }\end{array}$ & $\begin{array}{c}75: 2 \\
\text { ryegrass- } \\
\text { cocksfoot }\end{array}$ & $\begin{array}{c}60: 40 \\
\text { ryegrass- } \\
\text { cocksfoot }\end{array}$ & $\begin{array}{c}\text { Pure } \\
\text { cocksfoot }\end{array}$ \\
\hline $\begin{array}{l}3 \text { months } \\
\text { Ryegrass }\end{array}$ & 80 & 65 & 49 & 32 & $<1$ \\
Cocksfoot & $<1$ & 10 & 25 & 39 & 72 \\
Legume & 20 & 25 & 26 & 29 & 28 \\
2 years* & & & & & \\
Ryegrass & 74 & 70 & 53 & 54 & 1 \\
Cocksfoot & 0 & 6 & 11 & 16 & 72 \\
Legumes & 7 & 5 & 9 & 7 & 4 \\
\hline
\end{tabular}

* The proportions of other grasses (4-8\%), weeds and litter (3-6\%) and bare ground $(11-16 \%)$ were similar across treatments.

Table 3 Mean and range of liveweight gains ( $g /$ day) of ewe lambs grazing different mixtures of ryegrass/cocksfoot pastures over one-month periods during autumn and summer, and pasture mass before and after grazing.

\begin{tabular}{lcccc}
\hline \multirow{2}{*}{ Pasture mix } & \multicolumn{2}{c}{ Liveweight gain (g/day) } & \multicolumn{2}{c}{ Pasture mass $(\mathrm{kg} / \mathrm{DM} / \mathrm{h})$} \\
& Mean & Range & start & end \\
\hline Pure ryegrass & 62 & -39.4 to 157.6 & 2030 & 350 \\
80:20 ryegrass:cocksfoot & 61 & -81.8 to 178.8 & 2090 & 1000 \\
75:25 ryegrass:cocksfoot & 71 & -30.3 to 184.9 & 1950 & 990 \\
60:40 ryegrass:cocksfoot & 78 & -18.2 to 162.1 & 1950 & 650 \\
Pure cocksfoot & 83 & -33.3 to 237.9 & 1930 & 770 \\
\hline
\end{tabular}

Table 4 Mean ( \pm S.E.M.) staggers score and number of lambs without staggers or displaying minimal, moderate or severe symptoms of staggers whilst grazing different mixtures of ryegrass/cocksfoot pastures over approximately one-month periods during autumn and summer.

\begin{tabular}{lcccccc}
\hline & Staggers & \multicolumn{4}{c}{ Lambs with staggers classed as } \\
Pasture mix & score & $\mathrm{n}$ & absent & minimal & moderate & severe \\
\hline Pure ryegrass & $3.1 \pm 0.24$ & 58 & 12 & 5 & 21 & 20 \\
80:20 ryegrass:cocksfoot & $2.9 \pm 0.24$ & 60 & 14 & 6 & 26 & 14 \\
75:25 ryegrass:cocksfoot & $2.2 \pm 0.20$ & 60 & 14 & 17 & 24 & 5 \\
60:40 ryegrass:cocksfoot & $2.4 \pm 0.20$ & 60 & 13 & 13 & 26 & 8 \\
Pure cocksfoot & $0.3 \pm 0.12$ & 61 & 53 & 3 & 3 & 0 \\
\hline
\end{tabular}

Sward components and ryegrass staggers

The morphological components temporal effects (as sward components were removed by grazing) of the sward had a significant affect on staggers score during the final grazing period (summer). In all the forage treatment combinations (except pure cocksfoot), staggers score increased as the proportions of ryegrass green leaf decreased and percentage dead increased (Figure 2). However, there was no significant effect of the proportion of ryegrass stem on staggers score as these did not significantly change over the grazing period within any treatment. Over time, as staggers score increased, so did the removal by grazing of live cocksfoot sward components relative to the rate of removal of ryegrass green leaf and stem (Figure 2), and this was increasingly evident in swards containing lower percentages of cocksfoot.

\section{Discussion}

Although providing perennial ryegrass with natural protection against insects, endophytic fungi are very toxic to grazing animals. This was evident in the 
Figure 1 Relationship between the amount of ryegrass present in the pasture sward at the beginning of grazing and the severity of staggers (upper graph) and liveweight gain (lower graph) in lambs 33-42 days later. Note that the data has been limited to those treatments and seasons where significant staggers was recorded.

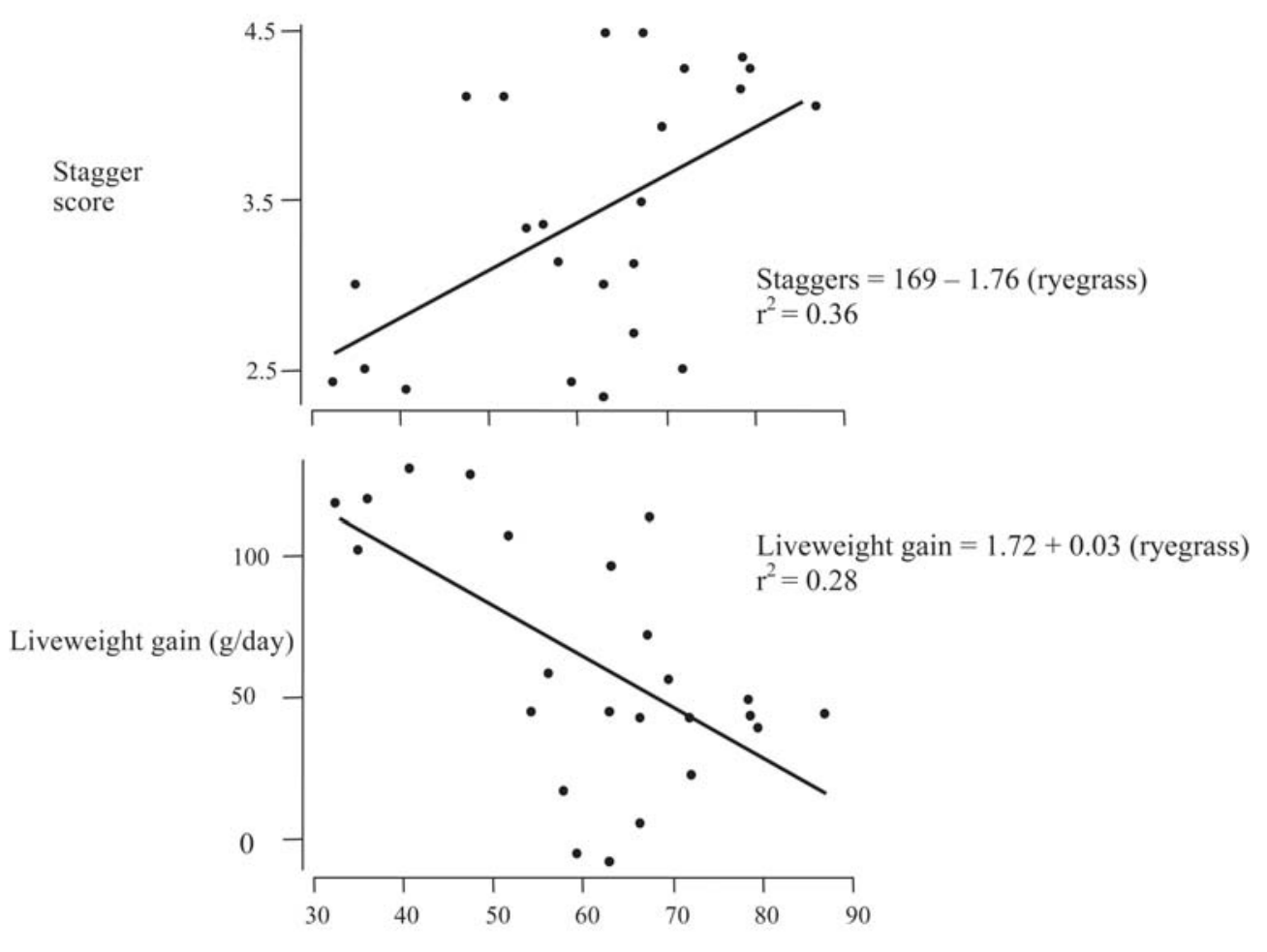

Ryegrass present in the sward (\%)

present study with $75 \%$ of lambs grazing ryegrass or ryegrass-dominant pastures exhibiting clinical signs of neurological disorder. These animals were significantly affected with symptoms ranging from slight trembling of the neck, shoulders, and flank muscles after exercise to severe muscle tremors elicited by disturbance or exercise invariably resulting in staggering and collapse in a tetanic spasm. The endophyte toxin is reasonably toxic, since even some animals grazing the pure cocksfoot treatment containing little ryegrass, exhibiting clinical symptoms, albeit minimal. While ryegrass staggers can result in significant mortality on farms (e.g. Milne et al. 1999) no deaths were associated with the present experiment.

The inclusion of cocksfoot in the ryegrass pasture did not affect the incidence of staggers $(80 \%$ of lambs grazing ryegrass-dominant pastures exhibited clinical signs) but, cocksfoot significantly reduced the severity of the disorder. While lambs were either severely or moderately affected when grazing 80 or $100 \%$ ryegrass treatments, they were only moderately or minimally affected when the proportion of ryegrass was 60 or $70 \%$. This experiment indicates that the inclusion of other grasses with perennial ryegrass in the pasture sward would be able to reduce the toxic effects of the ryegrass. Whether this reflects physiological or metabolic dilution of toxins after ingestion or animal grazing preference for selecting non-toxic forage is unclear. Some evidence for the latter mechanism was seen in the increased grazing of cocksfoot sward components rather than ryegrass as the staggers score increased over time (Figure 2). The lambs may select different pasture species in response to the level of toxicity experienced. For instance stock will selectively graze swards uninfected by endophyte more severely that infected swards (Edwards et al. 1993). Preferential grazing for cocksfoot may also have been associated with the loss of the preferred parts of the ryegrass sward making the cocksfoot relatively more attractive. While cocksfoot reduced or diluted the toxic effects of ryegrass in the present experiment, others species could also be effective (Keogh 1986). The ability of some pasture species to counter the adverse effects of toxic species, or even enhance the beneficial effects of others, is therefore open to much investigation. Not only which species, but in what proportions are they 
required in order to be most effective and how could they be offered in the grazing system, presents many options.

Lamb liveweight gain has been reported (Fletcher et al. 1999) to have been reduced by up to $10 \mathrm{~g} / \mathrm{d}$ in summer and autumn, for every $10 \%$ increase in endophyte infection, though there was variation between years and localities. The range in individual liveweight gains in the present study was large (-82 to $238 \mathrm{~g} / \mathrm{d}$ ), possibly precluding detection of any overall relationship between pasture mix (and thus endophyte) and liveweight gain. When the incidence of staggers was significant though (removing the first grazing run from the analysis), as ryegrass content increased, so did ryegrass staggers, while liveweight gain decreased (Figure 1). This highlights the difficulty of separating the effects of ryegrass availability on either ryegrass staggers or liveweight gain. The reason for the low incidence of staggers in the first grazing period compared with the later periods is unknown, though environmental factors such as water availability are thought to affect the expression of endophyte toxins (Lane et al. 1997).

Essentially monocultural or bicultural pastures are a feature of many modern pastoral farming systems. While they may present opportunities for enhanced livestock production, they also reduce selective grazing opportunities for animals. Farm animal species have evolved in the presence of many forage species, providing a varied diet not often seen on most modern farms (Fisher \& Bryant 1993). Access to varied forage species may be important to the animal for several reasons, one being self-medication (Clayton \& Wolfe 1993). This aspect of animal husbandry requires more serious consideration as modern systems reflect our expectations of increased productivity rather than acknowledging the sometimes subtle, needs of animals. The establishment of pastures containing a diversity of forage species might favour animal health.

\section{ACKNOWLEDGEMENTS}

The authors wish to thank the Foundation of Research, Science and Technology for funding this research.

\section{REFERENCES}

Bluett, S.J.; Hodgson, J .; Kemp, P.D.; Barry, T.N. 1997. Animal evaluation of Aries HD perennial ryegrass selected for high digestibility. Proceedings of the New Zealand Grassland Association 59: 245-249. Clayton, D.H. and Wolfe, N.D. 1993. The adaptive significance of self-medication. Trends in Ecology and Evolution 8 (2): 60-63.

Eerens, J.P.J.; Ryan, D.L.; Miller, K.B. 1992. The ryegrass endophyte in a cool moist environment. Proceedings of the New Zealand Grassland Association 54: 157-160.

Easton, H.S. 1999. Endophyte in New Zealand ryegrass pastures, an overview. pp 1-9 In: Ryegrass Endophyte: An Essential New Zealand Symbiosis. Eds. D.R. Woodfield; C. Matthew. Grassland Research and Practice Series 7. New Zealand Grassland Association, Palmerston North.

Edwards, G.R.; Lucas, R.J.; Johnson, M.R. 1993. Grazing preference for pasture species by sheep is affected by endophyte and nitrogen fertility. Proceedings of the New Zealand Grassland Association 55: 137-141.

Fisher, M.W.; Bryant, L.D. 1993. What might be the consequences of adapting wild animals, such as wapiti, to a farm environment? Proceedings of the New Zealand Society of Animal Production 53: 457460.

Fletcher, L.R. 1983. Effects of presence of Lolium endophyte on growth rates of weaned lambs, growing on to hoggets, on various ryegrasses. Proceedings of the New Zealand Grassland Association 44: 237-239.

Fletcher, L.R.; Borrell, G.K. 1984. Reduced liveweight gains and serum prolactin levels in hoggets grazing ryegrass containing Lolium endophyte. New Zealand Veterinary Journal 32: 139-140.

Fletcher, L.R.; Sutherland, B.L.; Fletcher, C.G. 1999. The impact of endophyte on the health and productivity of sheep grazing ryegrass-based pastures. pp 11-17. In: Ryegrass Endophyte: An Essential New Zealand Symbiosis. Eds. D.R. Woodfield; C. Matthew. Grassland Research and Practice Series 7. New Zealand Grassland Association, Palmerston North.

Gallagher, R.T.; White, E.P.; Mortimer, P.H. 1981. Ryegrass staggers: isolation of potent neurotoxins lolitrem A and lolitrem B from staggers producing pastures. New Zealand Veterinary Journal 29:189190.

Keogh, R.G. 1973. Induction and prevention of ryegrass staggers in grazing sheep. New Zealand Journal of Experimental Agriculture 1: 55-57.

Keogh, R.G. 1983. Ryegrass staggers: management and control. Proceedings of the New Zealand Grassland Association 44: 248-250.

Keogh, R.G. 1986. Fungal distribution and livestock defoliation patterns in pasture ecosystems, and the development and control of dietary-dependent disorders. Proceedings of the New Zealand Grassland Association 47: 93-98.

Keogh, R.G.; Clements, R.J 1993. Grazing management: a basis for control of ryegrass staggers. 
pp. 129-131. In: Proceedings of the Second International Symposium on Acremonium / Grass Interactions. Eds. C.W. Bacon; N.S. Hill. Plenum Press, New York.

Korte, C.J.; Smith, D.R. 1993. Animal toxicity problems perceived to be associated with different pasture types on East Coast sheep/beef farms. Proceedings of the New Zealand Society of Animal Production 53: 133-137.

Lane, G.A.; Tapper, B.A.; Davies, E.; Hume, D.E.; Latch, G.C.M.; Barker, D.J.; Easton, H.S .; Rolston, M.P. 1997. Effect of growth conditions on alkaloid concentrations in perennial ryegrass naturally infected with endophyte. pp 179-182. In: Proceedings of the Second International Symposium on Acremonium / Grass Interactions. Eds. C.W Bacon; N.S. Hill. Plenum Press, New York.

McCullagh, P.; Nelder, F.R.S. 1983. Generalized linear models. Eds. D.R. Cox and D.V. Hinkley. University Press, Cambridge.

McKenzie, J.R.; Everest, P.G. 1985. Nutrimol trough treatment on ryegrass staggers in cattle. New Zealand Journal of Agriculture 150(6): 16-18.

McKenzie, R. 1982. Prevention of ryegrass staggers. New Zealand Veterinary Joumal 30(10): 161-162.

Milne, G.D.; Russell, A.H.; Russell, J.R.; Russell, S.W. and Russell, P.A. 1999. Experiences of ryegrass endophyte on farms on the East Coast of the North Island. pp. 33-37. In: Ryegrass Endophyte: An Essential New Zealand Symbiosis. Eds. D.R. Woodfield; C. Matthew. Grassland Research and Practice Series 7. New Zealand Grassland Association, Palmerston North.

Milne, G.D.; Shaw, R.; Powell, R.; Pirie, B. and Pirie, J. 1997. Tall fescue use on dairy farms. Proceedings of the New Zealand Grassland Association 59: 163-167.

Moris, C.A.; Towers, N.R.; Wheeler, M.; Amyes, N.C. 1995. A note on the genetics of resistance or susceptibility to ryegrass staggers in sheep. New Zealand Journal of Agricultural Research 38: 367-371.
Morris, C.A.; Towers, N.R.; Amyes, N.C.; Wheeler, M. 1998. Preliminary results of selecting sheep for resistance or susceptibility to ryegrass staggers. Proceedings of the New Zealand Society of Animal Production 58: 154-156.

Morris, C.A. 1999. Six years of selection responses for resistance or susceptibility to ryegrass staggers in sheep. pp. 27-31. In: Ryegrass Endophyte: An Essential New Zealand Symbiosis. Eds. D.R. Woodfield; C. Matthew. Grassland Research and Practice Series 7. New Zealand Grassland Association, Palmerston North.

Payne, R.W. 1993. Genstat 5 Reference Manual, release 3. Lawes Agricultural Trust. Clarendon Press, Oxford, United Kingdom.

Popay, A.J.; Hume, D.E.; Baltus, J.G.; Latch, G.C.M.; Tapper, B.A.; Lyons, T.B.; Cooper, B.M.; Pennell, C.G.; Eerens, J.P.J.; Marshall, S.L. 1999. Field performance of perennial ryegrass (Lolium perenne) infected with toxin-free fungal endophytes (Neotyphodium spp.) pp. 113-122. In: Ryegrass Endophyte: An Essential New Zealand Symbiosis. Eds. D.R. Woodfield; C. Matthew. Grassland Research and Practice Series 7. New Zealand Grassland Association, Palmerston North.

Prestidge, R.A. 1993: Causes and control of perennial ryegrass staggers in New Zealand. Agriculture, Ecosystems and Environment 44: 283-300.

Smith, D.R.; Slay, M.W.A.; Gray, M.H.; Milne, G.D. 1993. On farm establishment of drought-tolerant pastures on the east coast of the North Island. Proceedings of the New Zealand Grassland Association 55: 33-38.

Thom, E.R.; Clark, D.A.; Waigh, C.D. 1999. Endophyte and dairy production in New Zealand: experience at the Dairying Research Corporation. pp 39-44. In: Ryegrass Endophyte: An Essential New Zealand Symbiosis. Eds. D.R. Woodfield; C. Matthew. Grassland Research and Practice Series 7. New Zealand Grassland Association, Palmerston North. 